\title{
KONSTRUKSI METODOLOGI TEOLOGI FEMINISME
}

\author{
Muhammad In'am Esha \\ Dosen Fakultas Humaniora dan Budaya \\ Universitas Islam Negeri (UIN) Malang
}

\begin{abstract}
ABSTRAK
This Article studies about methodology construction used in feminism theology. Riffat Hassan's thought made as a model in this article. There are several things which can be understood in this article namely: First, feminism theology which emerges in domain of modern Islamic thought cannot be discharged from a global tendency of this discourse growth in America. Second, in the context of "Islamicate", the emergence of feminism theology is pushed by a social reality in Islamic society which still have discrimination and subjugation toward woman. Particularly, this matter is legitimized by religious doctrines. Third, methodologically speaking, feminism theology has been reconstructed by using ideal, historical and empirical-normative approaches as well as by deconstruction, hermeneutic and hadits criticism methods. By these approaches and methods, feminism theology becomes one of discourses for woman to fight againts discrimination and subjugation
\end{abstract}

\section{A. Pendahuluan}

Salah satu hal terpenting ketika menelaah sebuah arus pemikiran yang berkembang dalam Islam adalah bagaimana mengkaji dan memahami kerangka metodologi yang digunakan. Hal ini dikatakan penting tidak lain karena kalau diibaratkan bahwa sebuah arus pemikiran sebagai sebuah produk dari pabrikan, maka konstruksi metodologi mencoba untuk memahami bagaimana sebuah produk itu muncul, bagaimana sebuah produk itu dihasilkan, bagaimana langkahlangkah yang dipakai. Demikian halnya dengan apa yang akan dibahas dalam tulisan ini. Kita akan mencoba untuk mengkaji bagaimana sebuah arus pemikiran teologi feminisme itu diproduksi dan dihasilkan dalam ranah pemikiran Islam modern.

Term metodologi secara sederhana berasal dari kata methodos dan logos. Biasa dipahami sebagai ilmu yang membahas tentang hal ihwal metode. Kata metode sendiri berasal dari kata Yunani methodeuo yang berarti mengikuti jejak 
atau mengusut, menyelidiki dan meneliti. Kata ini berasal dari kata methodos yang berasal dari akar kata meta (maknanya dengan) dan hodos (maknanya jalan). Dalam konteks ini, kita menjadi paham mengapa kemudian metode ini sangat lekat dan dekat dengan aktivitas penelitian atau riset. ${ }^{1}$

Dalam hubungannya dengan aktivitas ilmiah, metode secara umum dipahami sebagai cara kerja yang teratur dan sistematis yang digunakan untuk memahami suatu objek yang dipermasalahkan, yang merupakan sasaran dari bidang ilmu tertentu. Dalam perkataan lain dapat dijelaskan bahwa metode merupakan langkah-langkah yang sistematis untuk menyelesaikan sebuah permasalahan. $^{2}$

Sebagaimana yang tergambar dalam judul tulisan ini, kita akan mencoba untuk mengkaji bagaimana kerangka metodologi yang digunakan dalam konteks teologi feminisme yang berkembang dalam pemikiran Islam. Secara sistematis tulisan ini akan mencakup pembahasan tentang: (1) Menggali akar Munculnya Teologi Feminisme dalam Islam, (2) Sebuah Pembacaan: Metodologi Riffat Hassan, (3) Penutup

\section{B. Menggali Akar: Kemunculan Teologi Feminisme}

Anita M. Weiss dalam The Slow Yet Steady Path to Women's Empowerment in Pakistan menjelaskan bahwa diskriminasi terhadap perempuan menampakkan pemandangan yang sangat kental. "all we can see is the public space of the male world", 3 demikianlah ungkapan Weiss ketika menggambarkan realitas yang terjadi di salah satu kota di Lahore, Wallet City. Hal ini terjadi tidak lain karena sebagian besar perempuan dibatasi ruang geraknya untuk lebih berkiprah dan berada di ruang domestik. "Most women spend the bulk of their lives phisically within their homes".

${ }^{1}$ Jan Hendrik Rapar, Pengantar Filsafat, (Yogyakarta: Kanisius, 1996), 93.

${ }^{2}$ Ibid, 93.

3 Anita M. Weiss, "The Slow yet Steady Path to Women's Empowerment in Pakistan", dalam Yvonne Yazbeck Haddad dan John L. Esposito, Islam, Gender, and Sosial Change, (New York-Oxford: Oxford University Press, 1980, 125.

${ }^{4}$ Anita M. Weiss, Ibid, 126. 
Berawal dari realitas semacam itulah kemudian muncul pertanyaan mengapa hal itu terjadi dalam Islam? Benarkah Islam yang diwahyukan kepada Muhammad saw dengan al-Qur'an sebagai sumber moral yang mengedepankan etos keadilan dan egaliterianisme mengajarkan diskriminasi? Benarkah Muhammad yang seringkali diklaim sebagai sosok pembebas mengajarkan subordinasi terhadap salah satu jenis mahluk Tuhan? Inilah beberapa pertanyaan intern yang seringkali dimunculkan di kalangan para pemikir feminisme dalam Islam.

Secara historis, diskriminasi terhadap perempuan muncul sebagai akibat adanya doktrin ketidaksetaraan laki-laki dan perempuan yang telah menghiasi kehidupan manusia dalam semua masyarakat di sepanjang zaman, kecuali dalam masyarakat matriarkal yang jumlahnya tidak seberapa. Adanya anggapananggapan bahwa perempuan tidak cocok memegang kekuasaan karena perempuan diklaim tidak memiliki kemampuan seperti yang dimiliki laki-laki, laki-laki harus memiliki dan mendominasi perempuan, menjadi pemimpinnya dan menentukan masa depannya, aktifitas perempuan dibatasi di rumah dan di dapur karena dianggap tidak mampu mengambil keputusan di luar wilayahnya, adalah performa subjugasi atau penundukan perempuan di bawah struktur kekuasaan laki-laki. ${ }^{5}$ Hal inilah yang kemudian memunculkan apa yang dikenal sebagai gerakan feminisme dalam Islam.

Diskursus feminisme pada awalnya mulai mencuat di Amerika Serikat pada tahun 1963 yang ditandai dengan terbitnya buku Betty Frieddan, The Feminine Mystique, yang isinya mempersoalkan praktik-praktik ketidakadilan yang menjadikan perempuan sebagai korban. Hal inilah yang kemudian beresonansi dalam ranah pemikiran Islam. ${ }^{6}$ Sebut saja beberapa nama-nama seperti Aminah Wadud-Muhsin, Laila Ahmed, Riffat Hassan, Fatimah Mernisi, Asghar Ali Engineer, Nasaruddin Umar, adalah sosok-sosok pemikir yang konsen dalam permasalahan ini.

Mencermati diskursus feminisme dalam Islam, setidaknya akan menyiratkan bahwa akar masalahnya berasal dari adanya kenyataan diskriminasi

\footnotetext{
${ }^{5}$ Asghar Ali Engineer, Hak-Hak Perempuan dalam Islam, (Yogyakarta: LSPPA, 2000), 63.

${ }^{6}$ M. Aunul Abied Shah, Malak Hifni Nashif Bek, Sosok Kartini Lembah Nil: Menggali Akar Feminisme di Dunia Islam, (Bandung: Mizan, 2001), 151.
} 
antara laki-laki dan perempuan. Secara sederhana hal ini dapat kita cermati sejarah panjang tidak diperkenankannya perempuan menjadi pemimpin negeri ini. Terlepas dari aspek politik yang ada pada saat itu, tampilnya Megawati sebagai Presiden tidaklah berjalan mulus. Banyak hambatan-hambatan teologis yang muncul pada saat itu. Megawati pada saat itu dihadapkan pada kenyataan tentang ketidakbolehan perempuan menjadi pemimpin negara.

Belum lagi kalau kita dicermati slogan-slogan masyarakat Jawa. Kalau kita sependapat dengan anggapan bahwa "bahasa menunjukkan bangsa" atau dalam bahasa ilmiahnya bahasa adalah cerminan dari realitas sosial yang sesungguhnya, maka kita akan dengan sangat sadar memahami betapa diskriminasi itu terjadi. Slogan-slogan seperti perempuan adalah konco wingking, suwargo nunut, neroko katut dan sebagainya telah menjadi cerminan realitas diskriminasi dalam tradisi kebudayaan Jawa.

Diskriminasi gender selain mendapatkan legitimasi dari tradisi sosial, seringkali diperkuat oleh "ajaran-ajaran" agama yang. Setidaknya terdapat beberapa hal yang menjadi akar terjadinya diskriminasidalam konteks agama. Pertama, bahwa ciptaan Tuhan yang utama adalah laki-laki bukan perempuan, karena telah diyakini bahwa perempuan diciptakan dari tulang rusuk laki-laki (Adam), sehingga secara ontologis bersifat derivatif dan sekunder. Kedua, bahwa perempuan adalah penyebab utama jatuhnya Adam dari surga, karena itu anak perempuan Hawa harus dipandang dengan rasa benci, curiga dan jijik. Ketiga, bahwa perempuan tidak saja dicipta dari laki-laki namun juga untuk laki-laki, sehingga eksistensinya bersifat instrumental dan tidak memiliki makna yang mendasar. $^{7}$

Oleh karena diskriminasi atas perempuan bila ditinjau dari akarnya juga sangat lekat dengan agama, maka tidak mengherankan jika kemudian muncul pemikiran-pemikiran yang seolah-olah bernada menggugat agama, keluar dari kelaziman. Secara sederhana dasar pemikiran mereka ini dapat diungkapkan seperti ini: kalau yang menjadi salah satu penyebab terjadinya diskriminasi itu adalah pembacaan, penafsiran, atau pemahaman agama, maka mau-tidak-mau jika ingin merubah model pemahaman tersebut adalah dengan melakukan kajian atas-

\footnotetext{
${ }^{7}$ Fatima Mernisi dan Riffat Hassan, Setara di Hadapan Allah, Op. Cit., 54.
} 
atas aspek-aspek keagamaan tersebut. Itulah sebabnya, dalam konteks ini medan perjuangan mereka senantiasa akan berkaitan untuk memberikan pembacaan dan pemahaman atas agama. Inilah yang kemudian kita kenal dengan teologi feminisme.

\section{Sebuah Pembacaan: Metodologi Riffat Hassan}

Sebagaimana telah disinggung di atas, bahwa terdapat beberapa pemikir muslim yang konsen terhadap masalah feminisme dalam Islam. Satu di antara mereka adalah Riffat Hassan. Metodologi yang digunakan Riffat Hassan inilah yang akan kita coba untuk dikaji dan dijadikan model dalam perspektif ini. Tetapi, ada baiknya sebelum lebih jauh membahas kerangka metodologinya kita akan paparkan dahulu sedikit informasi tentang tokoh yang kita jadikan model ini.

Riffat Hassan adalah seorang tokoh feminisme yang berasal dari Pakistan, tepatnya di kota Lahore. Belum didapat infomasi yang jelas tentang kapan Riffat dilahirkan kecuali bahwa ia berasal dari keluarga Sayyid kelas atas dan ia adalah salah seorang putri dari sembilan bersaudara --saudaranya terdiri atas lima lakilaki dan tiga perempuan. Ayahnya yang biasa dipanggil "Begum Shahiba" adalah patriarkh di daerah itu. Sangat dihormati dan sekaligus sangat tradisional pandangannya. Sementara ibunya merupakan adalah anak dari seorang penyair, dramawan dan ilmuwan terkemuka, Hakim Ahmad Shuja'.

Debut awal ketertarikannya pada masalah feminisme terjadi pada tahun 1983-1984 ketika ia terlibat dalam satu proyek penelitian di Pakistan. Ketika itu masa pemerintahan Zia dan Islamisasi sedang dimulai. Pertanyaan yang timbul di benaknya pada waktu itu, mengapa kalau satu negara atau pemerintahan mulai melakukan Islamisasi, tindakan pertama yang dilakukan adalah memaksa perempuan kembali masuk rumah, menutup seluruh tubuh mereka, memberlakukan peraturan dan undang-undang yang mengatur tingkah laku individu, terutama perempuan? Dia kemudian mempelajari teks al-Qur'an secara serius dan mendalam dan akhirnya melihat perlunya reinterpretasi. ${ }^{8}$

\footnotetext{
${ }^{8}$ Riffat Hassan, "Feminisme dan al-Qur'an", dalam Jurnal Ulumul Qur'an No. 09, Vol. II, Tahun 1991, 86.
} 
Pendidikan tingginya ditempuh di Inggris di St. Mary's College University of Durham. Riffat berhasil menyelesaikan studinya di bidang sastra Inggris dan filsafat dalam waktu tiga tahun dan meraih predikat cumlaude. Riffat sudah mengantongi gelar doktornya dengan desertasinya tentang filsafat Muhammad Iqbal -- seorang pemikir Pakistan modern yang dikaguminya -- dalam usianya yang relatif muda, 24 tahun. ${ }^{9}$ Karir intelektual Riffat mulai menampakkan kemantapannya sejak ia menetap di Amerika Serikat pada tahun 1976. Di negara ini, ia menduduki jabatan sebagai Ketua Jurusan Religious Study Program di University of Lousville, Kentucky. Selain itu, ia juga menjadi dosen tamu di Harvard Divinity School. Pada saat menjadi dosen tamu inilah ia berhasil menyelesaikan karyanya Equal Before Allah yang di dasarkan pada risetnya selama setahun (1986-1987). Ia juga menjabat sebagai penasehat guru besar Perhimpunan Mahasiswa Muslim di University Oklahoma, Stillwater. ${ }^{10}$

Dalam konteks membangun dan mengembangkan sebuah pemikiran, hal mendasar yang mesti adalah apa dan bagaimana sebuah kerangka metodologi dibangun. Hal ini tidak lain karena metodologi memiliki peranan yang sangat signifikan dan niscaya. Metodologi merupakan motor penggerak fundamental bagi pengembangan dan konstruksi sebuah keilmuan. Oleh karena peranan metodologi yang sedemikian penting, tidaklah berlebihan bila Mukti Ali mengatakan bahwa yang menentukan realitas stagnasi dan inkrisi suatu keilmuan bukanlah terletak pada ada atau tidak adanya orang jenius melainkan lebih ditentukan pada kerangka metodologi. ${ }^{11}$ Demikian halnya dengan Riffat Hassan, dalam upayanya untuk membangun dan mengembangkan pemikiran teologi feminismenya, ia pun tidak luput dari kerangka metodologis yang dibangunnya. Pada bagian berikut ini penulis akan mencoba menguraikan kerangka metodologi yang dikonstruksi Riffat Hassan.

Sebelum lebih lanjut penulis membahas kerangka metodologis teologi feminisme Riffat Hassan, ada baiknya terlebih dahulu dijelaskan bagaimana pendekatan (approach) yang digunakan Riffat dalam konstruksi pemikirannya.

\footnotetext{
${ }^{9}$ Fatima Mernisi dan Riffat Hassan, Op. Cit., 25.

${ }^{10}$ Tentang Karirnya ini lebih lanjut lihat pada halaman-halaman terakhir dalam Fatima Mernisi dan Riffat Hassan, Ibid.

11 Mukti Ali, "Metodologi Ilmu Agama Islam", dalam Taufik Abdullah dan M. Rusli Karim, Metodologi Penelitian Agama: Sebuah Pengantar, (Yogyakarta: Tiara Wacana, 1989), 44.
} 
Sebagaimana dijelaskan dalam salah satu artikel yang dimuat jurnal Ulumul Qur'an, Feminisme dan al-Qur'an -- artikel ini merupakan hasil wawancara Wardah Hafidz dengan Riffat Hassan -- dalam membangun pemikiran teologi feminismenya, Riffat menggunakan pendekatan dua level yaitu: Pertama, pendekatan ideal-normatif. Pendekatan ini ditempuh untuk melihat bagaimana alQur'an menggariskan prinsip-prinsip ideal-normatif tentang perempuan. Seperti bagaimana seharusnya perempuan itu menurut al-Qur'an, tingkah lakunya, relasinya dengan Tuhannya, orang lain maupun dirinya sendiri. Kedua, pendekatan empiris. Pendekatan ini dilakukan dalam rangka untuk melihat secara empirik realitas sosiologis yang terjadi dan dialami perempuan. Misalnya, bagaimana perempuan memandang dirinya dan bagaimana orang lain memandang perempuan dalam masyarakat Islam. ${ }^{12}$ Dua pendekatan ini dalam realitasnya merupakan intertwine. Dalam pengertian bahwa di antara kedua pendekatan tersebut merupakan dua hal yang tidak dapat dipisahkan. Ia adalah satu kesatuan. Melalui dua pendekatan ini Riffat berupaya mendapatkan realitas empirik sekaligus gambaran idealis-normatif sehingga memungkinkannya untuk mengadakan evaluasi, penilaian dan kritik terhadap realitas yang dialami kaumnya. Berdasarkan pendekatan ini Riffat mampu membaca adanya kesenjangan antara idealitas-normatif dan realitas empiris yang dialami kaum perempuan. ${ }^{13}$ Hal inilah yang kemudian mendorongnya untuk melakukan pelacakan dan sekaligus pengkajian secara mendalam terhadap 'teks-teks' keagamaan yang telah membentuk sedimen dalam realitas sosio-historis masyarakat Muslim.

Selain pendekatan di atas, Riffat juga menggunakan pendekatan historis di dalam membangun pemikiran teologi feminismenya. Hal ini adalah sesuatu yang secara niscaya mesti dilakukan dalam rangka untuk mencermati secara kritis realitas Islam yang telah berdiri kokoh dalam bangunan sejarah. Sebagaimana dijelaskan oleh Charles J. Adams dalam Islamic Religious Tradition bahwa untuk dapat memberikan pemaknaan yang benar terhadap Islam, pendekatan historis adalah sebuah keniscayaan. Hal ini tidak lain karena Islam sebagai sebuah visi hidup dalam realitasnya tidak sepi dari dialektikanya dengan realitas sejarah yang

12 ibid. 87. 
selalu berubah dan berkembang. ${ }^{14}$ Pendekatan historis ini dengan jelas dapat kita cermati dari sebaran pemikiran-pemikiran Riffat. Seperti kritik yang dikemukannya berkenaan dengan mainstream penafsiran al-Qur'an yang dalam realitas sejarahnya menampakkan performa patriarchy oriented yang nota bene telah menjadikan perempuan tersubordinasi dan menjadi second class citizen. Hal tersebut adalah realitas tak terbantahkan digunakannya pendekatan historis. ${ }^{15}$ Tanpa pendekatan kesejarahan adalah sulit bagi Riffat untuk melakukan hal tersebut.

Penggunaan pendekatan-pendekatan sebagaimana tersebut di atas adalah sesuatu yang mesti dilakukan sebagai titik pijak (vantage point) dalam konstruksi pemikiran feminisnya. ${ }^{16}$ Melalui pendekatan yang dipilihnya ini memungkinkan Riffat untuk secara leluasa melakukan pengkajian-pengkajian berkenaan dengan 'teks-teks' yang terhampar dalam realitas empiris sosiologis maupun yang telah terekam dalam sejarah peradaban manusia melalui warisan tertulisnya. Pendekatan ini kemudian dikombinasikan dengan serangkaian kerangka metodologi. Riffat dalam hal ini memang tidak secara eksplisit-holistik menjelaskan kerangka metodologi yang gunakan. Namun demikian, berdasarkan sebaran pemikiran yang dikedepankannya, kita setidaknya bisa melacak dan membuat konstruksi berkenaan dengan hal tersebut. Berikut akan dijelaskan konstruksi metodologi teologi feminisme Riffat Hassan.

Pertama, metode dekonstruksi. Metode ini digunakan Riffat sebagai sebuah keniscayaan tidak lain karena hakekat dicetuskannya ide tentang teologi feminisme tidak lain adalah untuk membongkar dan melakukan kritik konstruktif terhadap berbagai konsep keagamaan yang bias patriakhi. Menurut Riffat, adanya diskriminasi dan segala bentuk ketidakadilan yang menimpa kaum perempuan dalam lingkungan umat Islam bersumber dari adanya pemahaman yang bias di

13 ibid, 87.

${ }^{14}$ Charles J. Adams, "Islamic Religious Tradition", dalam Leonard Binder (ed.), The Study of the Middle East, (Canada: John Wiley \& Sons, Inc., 1976), 31. Cit., 49.

${ }^{15}$ Riffat Hassan, Teologi Perempuan dalam Tradisi Islam: Sejajar di Hadapan Allah?, Op.

${ }^{16}$ Penjelasan tentang apa dan bagaimana pendekatan (approach), lebih lanjut lihat dalam Walter H. Capps, Religious Studies, The Making of a Discipline, (Minneapolis: Forrtrress Press, 1995), 334; Bandingkan juga dengan penjelasan pengantar Peter Connolly dalam Peterr Connolly (ed.), Approaches to the Study of Religion, (London: Wellington House, 1999), 1-9. 
mana orientasi patriarkhi sangat kental mewarnai wajah-wajah pemahaman alQur'an. Al-Qur'an adalah sumber utama dan paling otoritatif dalam tradisi Islam. 'Of all the sources of Islamic tradition, undoubtedly, the most important is the Qur'an which is regarded by Muslims in general, as primary and most authoritative sources of normative Islam, ${ }^{17}$ demikian Riffat menjelaskan. Pemahaman yang male bias terhadap Al-Qur'an ini tentunya akan berpengaruh terhadap sumber-sumber yang menjadi landasan tradisi Islam yang lain seperti fiqh. Tidaklah mengherankan jika dalam sejarahnya kaum perempuan selama ini tetap berada dalam realitasnya yang tercerabut hak-hak kemanusiaannya. ${ }^{18}$

Upaya dekonstruksi pemikiran teologis yang selama ini menyudutkan perempuan ke pojok-pojok sejarah kemanusiaannya, dengan demikian, adalah sebuah keniscayaan. Teologi yang menampilkan wajahnya yang misoginis dan androsentris mesti diturunkan dari panggung sejarah dan sudah saatnya ditampilkan performa teologi yang berkeadilan dalam memposisikan perempuan. 'Saat ini kita harus mengembangkan apa yang disebut oleh orang Barat sebagai teologi feminisme', 19 demikian Riffat. Dekonstruksi teologi perempuan "klasik" tetap menjadi sebuah keniscayaan meskipun terdapat perbaikan-perbaikan secara statistik seperti dalam pendidikan, pekerjaan dan hak-hak sosio-politik. Hal ini tidak lain karena realitas diskriminasi dan perlakuan tidak adil terhadap perempuan akan terus berlangsung jika landasan teologis yang melahirkan kecenderungan-kecenderungan yang bersifat misoginis dalam tradisi Islam tersebut tidak dibongkar.

Dalam bukunya Women's dan Men's Liberation: Testimonies of Spirit dengan tegas ia mengatakan:

... that unless, or until the theological foundation of misogynistic and androcentric tendencies in Islamic traditions are demolished, muslim women will continue to be brutalized and discriminated against despite improvements in statistics such as those on female education, employment, and social dan political right. ${ }^{20}$

17 Riffat Hassan, Are Human Right Compatible with Islam? The Issue of the Right of Women in Muslim Communities, dalam Jurnal Profetika, Vol 3, No. 1, Jauarri 2001, 26.

${ }^{18}$ Riffat Hassan, Teologi Perempuan dalam Tradisi Islam: Sejajar di Hadapan Allah?, Op. Cit., 49

${ }^{19}$ Fatima Mernisi dan Riffat Hassan, Op. Cit., 49.

20 Riffat Hassan, Women's and Men's Liberation: Testimonies of Spirit, (New York: Grenwood Press, 1991), 67-68. 
Kedua, metode hermeneutik. Salah satu upaya signifikan yang mesti dilakukan berkaitan dengan adanya realitas ketidakadilan terhadap perempuan adalah dengan melakukan reinterpretasi terhadap teks-teks al-Qur'an yang selama ini dijadikan instrumen legitimasi bagi tindakan-tindakan diskriminasi terhadap perempuan. Dalam konteks ini metode hermeneutik menjadi sebuah keniscayaan. Hermeneutik, sebagaimana asal katanya 'hermeneutikos' yang berarti 'upaya menjelaskan dan menelusuri', ${ }^{21}$ adalah sebuah upaya menghadirkan, membaca, dan memaknai kembali sebuah 'teks' masa lalu sehingga sesuai dengan realitas kekinian. Carl Braaten dalam History and Hermeneutics secara lebih detail menjelaskan bahwa hermeneutik adalah 'sebuah ilmu yang mencoba menggambarkan bagaimana sebuah kata atau suatu kejadian dalam waktu dan budaya lampau dapat dimengerti dan menjadi bermakna secara eksistensial dalam situasi sekarang,. ${ }^{22}$ Hermeneutik, dengan demikian, dapat kita fahami akan senantiasa melibatkan tiga hal mendasar yaitu teks, konteks dan kontekstualisasi. Melalui metode hermeneutik ini Riffat melakukan pengkajian kembali terhadap teks-teks al-Qur'an dalam relasinya dengan teologi feminisme yang dikonstruksinya.

Dalam kinerja hermeneutiknya, sebagaimana dijelaskan dalam Women's Interpretation of Islam, Riffat menggunakan tiga prinsip utama dalam interpretasi, yaitu: Pertama, akurasi linguistik. Prinsip ini pada dasarnya berupaya untuk mendapatkan makna sebuah terma atau konsep secara tepat dengan melihat dan merujuk kepada semua leksikon klasik dan lain-lain apa yang dimaksud dengan kata itu dalam kebudayaan di mana ia dipergunakan. Kedua, kriteria konsistensi filosofis (criterion of philosophical consistency). Prinsip ini adalah untuk melihat bagaimana berbagai penggunaan kata-kata (dalam al-Qur'an) itu secara filosofis konsisten dan tidak bertentangan. Ketiga, kriteria etis (ethical criterion). Prinsip ini digunakan sebagai acuan dan bingkai (frame) utama dalam melakukan kritik, evaluasi dan sekaligus langkah progresif dalam "membaca" al-Qur'an. "Apabila Tuhan adil, keadilan itu haruslah terefleksikan di dalam al-Qur'an. Tuhan tidak dapat melakukan ketidakadilan. Apabila tampak ketidakadilan di dalam al-Qur'an,

\footnotetext{
${ }^{21}$ Hidayat, Komaruddin. Memahami Bahasa Agama: Sebuah Kajian Hermeneutik. Jakarta: Paramadina, 1996, 126.

${ }^{22}$ Carl Braaten, History and Hermeneutics, (Philadelphia: Forterrs, 1966, 131.
} 
meskipun dari sudut pandang manusia, penafsir haruslah berupaya mendapatkan sebuah interpretasi yang lebih adil dan pantas tentangnya". ${ }^{23}$

Aplikasi metodologis ini dapat dengan jelas kita lihat misalnya ketika Riffat menjelaskan dan melakukan reinterpretasi kata 'adam. Reinterpretasi ini menjadi keniscayaan dalam konteks teologi feminismenya tidak lain karena sebagaimana diketahui bahwa terdapat asumsi teologis mendasar yang menjadikan perasaan superioritas laki-laki atas perempuan, dari sisi penciptaan, adam adalah sosok mahluk pertama maskulin dan berasal dari padanya penciptaan Hawwa berasal. Riffat pun mempertanyakan, benarkah adam sebagai mahluk yang pertama kali diciptakan tersebut sosok laki-laki sebagaimana yang menjadi maistream pemikiran umat Islam selama ini? Dalam upaya pembacaan ulang tersebut, Riffat melakukan pelacakan terminologis untuk mendapatkan maknanya yang akurat.

Kata adam adalah istilah Ibrani berasal dari kata adamah yang artinya tanah. Kata yang muncul di dalam al-Qur'an sebanyak dua puluh lima kali ini dalam relasinya dengan fenomena penciptaan manusia hanya muncul sekali, Surat Ali Imran, 3: 59 dan itu pun hanya berbicara dalam konteks bahwa adam adalah sosok mahluk yang diciptakan dari tanah dan sama sekali tidak menjelaskan secara eksplisit tentang jenis kelaminnya. ${ }^{24}$ Pemaknaan bahwa adam berjenis kelamin maskulin, menurut Riffat, tidak lain berasal dari "analisis" linguistik yang selama ini dilakukan oleh para interpretator. Secara linguistik kata benda itu memang maskulin namun bukan menyangkut jenis kelamin, bahkan berdasarkan pemahaman terhadap ayat-ayat lainnya seperti surat al-A'raf, 7: 26, 27, 31, 35, 172; dan al-Isra', 17: 70, istilah "adam" berfungsi sebagai kata benda kolektif dan mengacu kepada seluruh manusia. ${ }^{25}$

Berdasarkan analisis tersebut sebuah kesimpulan meyakinkan yang dapat ditarik, adalah tidak bisa langsung diartikan bahwa adam itu laki-laki. “Al-Qur'an

${ }^{23}$ Riffat Hassan, "Women's Interprretation of Islam", dalam Hans Thijsen (ed.), Women and Islam in Muslim Society, (The Hague: Ministry of Foreign Affairs, 1994), 116.

${ }^{24}$ Ayat tersebut menyatakan, "Sesungguhnya (penciptaan) Isa di sisi Allah adalah seperti (penciptaan) Adam. Allah menciptakan Adam dari tanah, kemudian Allah berfirman kepadanya: "Jadilah", maka jadilah dia".

${ }^{25}$ Riffat Hassan,"Equal Before Allah, Women-Men Equality in Islamic Tradition", dalam Women Living Under Muslim Laws, kumpulan artikel dari The Commite on South Asian Women's Bulletin, Vol: IV, 1986, 16; Fatima Mernisi dan Riffat Hassan, Op. Cit., 58. 
tidak pernah menyatakan bahwa adam adalah manusia pertama dan tidak pula menyatakan bahwa ia laki-laki", ${ }^{26}$ demikian kata Riffat. Hal ini berarti bahwa pemahaman secara kontekstual terhadap term adam dan zauj sebagaimana yang terdapat dalam surat al-Baqarah, 2: 35, al-A'raf, 7: 19 dan Taha, 20: 117 menjadi sebuah kemestian. Kata zauj yang biasa ditafsirkan sebagai 'Hawwa', ${ }^{27}$ bagi Riffat, menjadi tidak relevan lagi. ${ }^{28}$ Hal ini tidak lain karena kalau term adam tidak lagi dimaknai sebagai sosok manusia maskulin, maka berarti kata zauj tidak dapat dimaknai sebagai 'Hawwa' yang feminim. Itulah sebabnya Riffat memaknainya secara kontekstual sebagai sesuatu yang menunjukkan terhadap pengalaman hidup manusia secara kolektif, laki-laki dan perempuan secara bersama-sama. $^{29}$ Melalui pembacaan ulang sebagaimana di atas, secara jelas Riffat telah melakukan kontekstualisasi terhadap teks al-Qur'an.

Mengingat teks-teks keagamaan yang menjadi sumber pembentukan tradisi Islam tidak hanya terletak dalam al-Qur'an melainkan juga hadis, maka metode kritik hadis menjadi sebuah keniscayaan bagi upaya konstruksi pemikiran feminismenya. Inilah metode ketiga yang dapat kita cermati dari realitas pemikirannya. Sebagaimana dijelaskan Riffat sendiri bahwa dalam upaya melakukan pelacakan terhadap akar teologis ketidaksejajaran laki-laki dan perempuan dalam tradisi Islam, pengkajian secara kritis terhadap hadis-hadis misoginis adalah sesuatu yang harus dilakukan. Kajian ini terutama ditujukan terhadap kitab Sahih al-Bukhari dan Sahih Muslim yang nota bene mempunyai otoritas tertinggi kedua di kalangan Muslim (Sunni). ${ }^{30}$ Hadis-hadis tentang penciptaan perempuan yang menjelaskan bahwa 'hawwa' diciptakan dan berasal dari tulang rusuk adam misalnya, melalui mekanisme metode kritik hadisnya, mencoba untuk diteliti dan dikaji ulang.

${ }^{26}$ Fatima Mernisi dan Riffat Hassan, Setara Di Hadapan Allah, Op. Cit., 59.

27 Lihat misalnya Abu al-Qasim Jarullah Mahmud ibn Umar al-Zamakhsyari alKhawarrizmi, al-Kasysyaf 'an Haqa'iq al-Tanzil wa 'Uyun al-'Aqawil fi al-Wujuh al-Tanzil, (Beirut: Dar al-Fikrr, 1977), II : 492; Abu al-Fadl Syihab al-Din al-Sayyid Mahmud Afandi alAlusi al-Bagdadi, Ruh al-Ma'ani fi Tafsir al-Qur'an wa al-Sab'i al-Masani, (ttp: Dar al-Fikr, tth), II : $180-181$.

${ }^{28}$ Fatima Mernisi dan Riffat Hassan, Ibid, 59-60.

${ }^{29}$ Riffat Hassan, Teologi Perempuan dalam Tradisi Islam: Sejajar di Hadapan Allah?, Op. Cit., 52.

${ }^{30}$ Riffat Hassan, Teologi Perempuan dalam Tradisi Islam: Sejajar di hadapan Allah?, Op. Cit., 50 . 
Metode kritik yang dilakukan Riffat terhadap hadis-hadis misoginis tersebut ditempuh dalam dua arah yaitu kritik sanad atau al-naqd al-khariji (kritik eksternal) dan kritik matan atau al-naqd al-dakhili (kritik internal). ${ }^{31}$ Dua model kritik tersebut menjadi satu kesatuan sistem kerja penelitian otentisitas hadis yang intertwine. Artinya, masing-masing elemen tidak dapat dipisahkan dari yang lain. Hal ini tidak lain karena tidaklah mungkin untuk mengetahui sebuah hadis itu sahih atau tidak tanpa melakukan dua model kritik tersebut sekaligus. ${ }^{32}$

\section{Penutup}

Sebagai sebuah model pembacaan metodologi dalam diskursus feminisme dalam Islam, tentunya hal ini harus dipahami sebagai sebuah cerminan. Apa yang dipakai oleh Riffat Hassan dalam konstruksi pemikirannya, bisa jadi akan mempunyai perbedaan dengan pemikir-pemikir sejenis yang lain.

Oleh karena itu, kajian-kajian yang lain masih perlu dilakukan. Namun, kita dapat mencermati bahwa berdasarkan pendekatan dan kerangka metodologi sebagaimana yang telah dijelaskan, Riffat berhasil menuangkan gagasangagasannya tentang teologi feminisme. Sebuah paradigma teologis yang menjadi keniscayaan dalam konteks pemikiran kontemporer sebagai salah satu ikhtiyar anak zaman dalam upaya memberangus realitas tradisi yang telah mengukuhkan androsentrisme dan berupaya menggantinya dengan wajah dunia yang lebih berkeadilan sesuai dengan misi kenabian Muhammad sebagaimana yang termaktub dalam al-Qur'an dan al-Sunnahnya. []

${ }^{31}$ Salahuddin al-Idlibi, Manhaj Naqd al-Matn 'Ind 'Ulama' al-Hadis al-Nabawi, (Beiut: Dar al-Afaq al-Jadidah, 1983), 31

${ }^{32}$ Metode kritik hadis pada prinsipnya adalah untuk mengetahui derajat kesahihan sebuah hadis. Dengan demikian, tolak ukurnya adalah kriteria dari sebuah hadis disebut sahih. Al-Suyuti menjelaskan bahwa terdapat lima syarat sebuah hadis disebut sahih: (1) Sanadnya bersambung; (2). Perawinya harus adil dan; (3) Bersifat dabit; (4) Dalam hadis tersebut tidak ada sesuatu yang janggal (syaz); dan (5) Tidak terdapat cacat ('ilah). Dari persyaratan tersebut dapat kita lihat, secara kategoris tiga kriteria pertama berkenaan dengan sanad dan dua terakhir berkenaan dengan sanad dan matan. Lebih lanjut baca Jalal al-Din al-Suyuti, Tadrib al-Rawi fi Sarh Taqrib alNabawi, (Madinah: al-Maktabah al-'Ilmiyah, 1972), I : 63. 


\section{DAFTAR PUSTAKA}

Rapar, Jan Hendrik. Pengantar Filsafat. Yogyakarta: Kanisius, 1996.

Weiss, Anita M. , “The Slow yet Steady Path to Women's Empowerment in Pakistan", dalam Yvonne Yazbeck Haddad dan John L. Esposito, Islam, Gender, and Sosial Change, New York-Oxford: Oxford University Press, 1980.

Engineer, Asghar Ali, Hak-Hak Perempuan dalam Islam, Yogyakarta: LSPPA, 2000.

Abied Shah, M. Aunu. Malak Hifni Nashif Bek, Sosok Kartini Lembah Nil: Menggali Akar Feminisme di Dunia Islam, Bandung: Mizan, 2001.

Hassan, Riffat "Feminisme dan al-Qur'an", dalam Jurnal Ulumul Qur'an No. 09, Vol. II, Tahun 1991.

Mukti Ali, "Metodologi Ilmu Agama Islam", dalam Taufik Abdullah dan M. Rusli Karim, Metodologi Penelitian Agama: Sebuah Pengantar, Yogyakarta: Tiara Wacana, 1989.

Adams, Charles J., "Islamic Religious Tradition", dalam Leonard Binder (ed.), The Study of the Middle East, Canada: John Wiley \& Sons, Inc., 1976.

Walter H. Capps, Religious Studies, The Making of a Discipline, Minneapolis: Forrtrress Press, 1995

Hassan, Riffat. "Are Human Right Compatible with Islam? The Issue of the Right of Women in Muslim Communities", dalam Jurnal Profetika, Vol 3, No. 1, Januari 2001.

Hassan, Riffat, Women's and Men's Liberation: Testimonies of Spirit, New York: Grenwood Press, 1991.

Hidayat, Komaruddin. Memahami Bahasa Agama: Sebuah Kajian Hermeneutik. Jakarta: Paramadina, 1996.

Braaten, Carl. History and Hermeneutics, Philadelphia: Forterrs, 1966.

Hassan, Riffat, "Women's Interprretation of Islam", dalam Hans Thijsen (ed.), Women and Islam in Muslim Society, The Hague: Ministry of Foreign Affairs, 1994.

Fatima Mernisi dan Riffat Hassan, Setara di Hadapan Allah, (terj.) Tim LSPPA, Yogyakarta: LSPPA, 2000.

Salahuddin al-Idlibi, Manhaj Naqd al-Matn 'Ind 'Ulama' al-Hadis al-Nabawi, Beirut: Dar al-Afaq al-Jadidah, 1983. 